\title{
A METAMATERIAL-EMBEDDED WIDE-BAND ANTENNA FOR THE MICROWAVE C-BAND
}

\author{
ŠIROKOPASOVNA ANTENA Z VGRAJENIM METAMATERIALOM \\ ZA MIKROVALOVNI C-PAS
}

\author{
Md. Ikbal Hossain ${ }^{1}$, Mohammad Rashed Iqbal Faruque', Mohammad Tariqul Islam², \\ Atiqur Rahman ${ }^{1}$ \\ 1Space Science Center (ANGKASA), 43600 UKM, Bangi, Selangor, Malaysia \\ 2University Kebangsaan Malaysia, Department of Electrical, Electronic and Systems Engineering, 43600 UKM, \\ Bangi, Selangor, Malaysia \\ ipk_eee@yahoo.com
}

Prejem rokopisa - received: 2015-06-30; sprejem za objavo - accepted for publication: 2015-12-15

doi:10.17222/mit.2015.145

\begin{abstract}
In this paper a metamaterial-embedded, compact microstrip-fed patch antenna is introduced for microwave C-band applications. The proposed antenna is composed of a rectangular metamaterial-embedded patch, microstrip-fed line and a partial ground plane. The finite-integration technique (FIT) based on Computer Simulation Technology (CST) Microwave Studio is utilized in this study. The measurements of antenna performances are conducted in a near-field measurement laboratory. The antenna performance parameters comprising the reflection coefficient, radiation efficiency, gain, and radiation pattern are studied to validate the antenna performance. The measured results show that the proposed metamaterial-embedded antenna exhibits a wide impedance bandwidth over the $\mathrm{C}$ band (from $3.77 \mathrm{GHz}$ to $6.58 \mathrm{GHz}$ ). The results also indicate good radiation efficiency and antenna gain with a nearly omni-directional radiation pattern at the frequencies of interest.

Keywords: antenna, head model, substrate material
\end{abstract}

$\mathrm{V}$ članku je predstavljena kompaktna mikrotrakasta antena $\mathrm{v}$ obliki obliža, z vgrajenim metamaterialom za uporabo $\mathrm{v}$ mikrovalovnem C-pasu. Predlagana antena je sestavljena iz v obliž vgrajenega metamateriala pravokotne oblike, iz linije iz mikrovlakna za napajanje in z delno ozemljeno površino. V študiji je uporabljena tehnika končne integracije (FIT), ki temelji na tehnologiji računalniške simulacije (CST) Microwave Studio. Meritve zmogljivosti antene so bile izvedene v gluhi sobi merilnega laboratorija. Za oceno zmogljivosti antene so bili izmerjeni parametri zmogljivosti, ki obsegajo koeficient refleksije, učinkovitost sevanja, izkoristek in sevalni diagram. Izmerjeni rezultati kažejo, da ima antena z vgrajenim metamaterialom širok impedančni pas v C pasu (od $3,77 \mathrm{GHz}$ do $6,58 \mathrm{GHz}$ ). Rezultati kažejo tudi na dobro učinkovitost sevanja antene in izkoristek antene s skoraj vsesmernim diagramom sevanja na frekvencah interesa.

Ključne besede: antena, glava modela, material podlage

\section{INTRODUCTION}

With the exponentially increasing need for electronic communications, interest in designing a broadband antenna with a wide frequency coverage is increasing. The microstrip antenna offers a low-profile, conformal design, ease of manufacture and integration, and it is low cost and lightweight. ${ }^{1}$ Although the microstrip patch antennas have a low profile and compact size characteristics, they suffer from a narrow bandwidth and low gain, and a poor polarization purity and tolerance problem. ${ }^{2-3}$ In the past decade, various techniques have been proposed to enhance the bandwidth of microstrip antennas with an increasing substrate thickness ${ }^{4}$, using slots on radiating patches ${ }^{5}$, using magneto dielectric substrates $^{6}$, and stacking different radiating elements. ${ }^{7}$

A wide-band antenna of wide-slot belonging to a microstrip line was designed using a fork-like tuning stub to increase the bandwidth. ${ }^{8}$ This design approach successfully showed a wide bandwidth but an antenna gain changing below $1.5 \mathrm{dBi}$ over the complete operational frequency bands. A slotted microstrip antenna was proposed for enhancing the bandwidth printed on an FR-4 substrate with about $2.01 \mathrm{dBi}$ antenna gain. ${ }^{9}$ Nowadays, metamaterials are being used in antenna engineering to enhance the antenna's performance and reduce the antenna's sizes. However, the electromagnetic band gap (EBG) or metamaterial can also be used to enhance the antenna performance, such as the antenna gain and impedance bandwidth. ${ }^{10}$ The bandwidth enhancement of a microstrop patch antenna was performed using planar artificial magnetic conductor (AMC) surface. ${ }^{11}$ A compact wide-band microstrip antenna was proposed with a modified patch and ground plane using a metamaterial. ${ }^{12}$

In this paper, a wide-band microstrip-fed patch antenna is proposed for microwave C-band radar applications. For the antenna-bandwidth enhancement, the metamaterial structure is incorporated with the antenna patch. Moreover, the antenna performance in terms of radiation efficiency, gain, and gain radiation pattern are analyzed in this study. 
Md. I. HOSSAIN et al.: A METAMATERIAL-EMBEDDED WIDE-BAND ANTENNA FOR THE MICROWAVE C-BAND
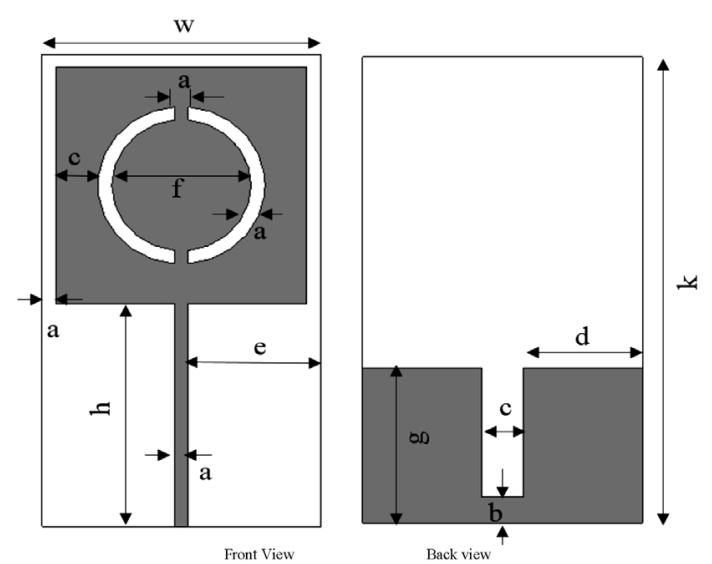

Figure 1: Proposed antenna geometry

Slika 1: Predlagana geometrija antene

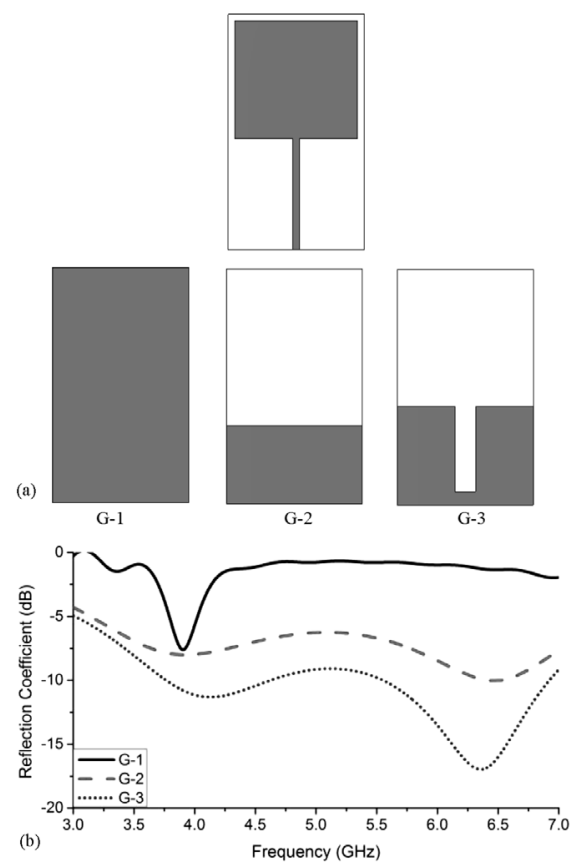

Figure 2: Antenna design phases: a) ground plane configurations and b) reflection coefficient for different configurations

Slika 2: Faze sestavljanja antene: a) konfiguracija osnovne plošče in b) koeficient odseva pri različnih konfiguracijah

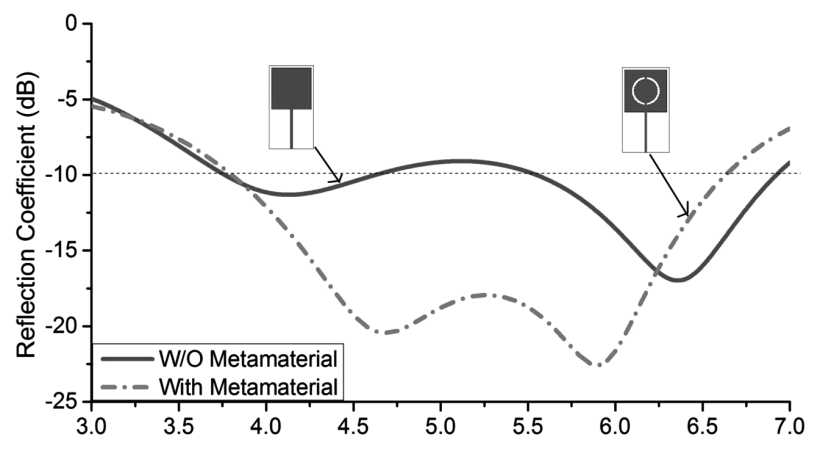

Figure 3: Reflection coefficient of proposed antenna with and without metamaterial

Slika 3: Koeficient sevanja predlagane antene, $\mathrm{z}$ in brez metamateriala

\section{ANTENNA DESIGN}

Figure 1 shows the geometry of the proposed microstrip antenna. The antenna consists of a rectangular patch with metamaterial, a partial ground plane and a printed microstrip line. A circular split-ring resonator with two slots is used as a metamaterial structure. The excitation is fed between the microstrip line and the ground using an SMA connector of $50 \Omega$ normalized impedance. A 0.8 -mm-thick, FR-4 sheet with a 4.6 relative permittivity is used as the substrate.

Table 1: Antenna design specifications Tabela 1: Specifikacija zgradbe antene

\begin{tabular}{|c|c|c|c|}
\hline Parameter & Value $(\mathrm{mm})$ & Parameter & Value $(\mathrm{mm})$ \\
\hline $\mathrm{a}$ & 1 & $\mathrm{f}$ & 10 \\
\hline $\mathrm{b}$ & 2 & $\mathrm{~g}$ & 12 \\
\hline $\mathrm{c}$ & 3 & $\mathrm{~h}$ & 17 \\
\hline $\mathrm{d}$ & 8.5 & $\mathrm{k}$ & 36 \\
\hline $\mathrm{e}$ & 9.5 & $\mathrm{w}$ & 20 \\
\hline
\end{tabular}

The antenna specifications are listed in Table 1. The antenna design investigation was based on the finite-instigation technique (FIT) of the CST microwave studio. A prototype of the proposed antenna is fabricated using

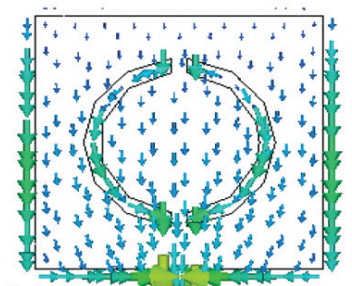

(a)

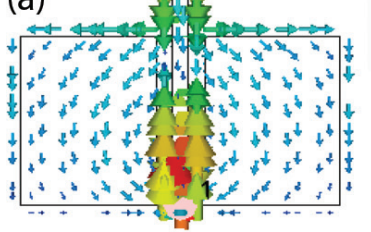

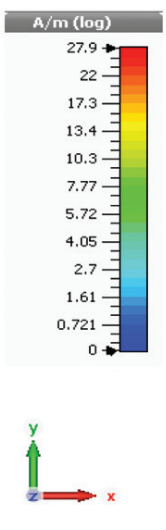
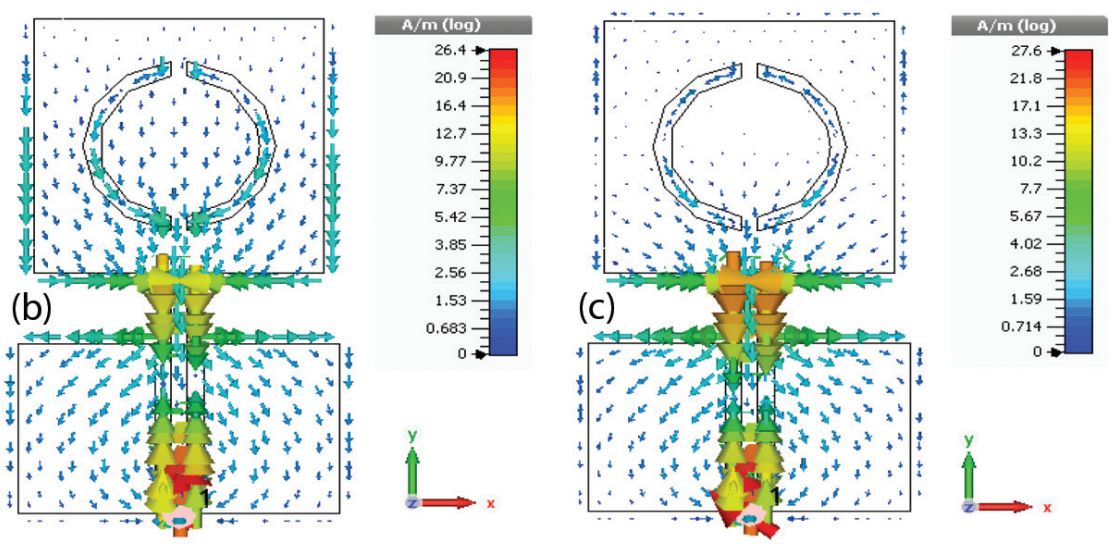

Figure 4: Surface current distribution of proposed antenna at: a) $4.5 \mathrm{GHz}$, b) $5 \mathrm{GHz}$ and c) $5.5 \mathrm{GHz}$ Slika 4: Razporeditev toka po površini predlagane antene pri: a) $4,5 \mathrm{GHz}$, b) $5 \mathrm{GHz}$ in c) $5,5 \mathrm{GHz}$ 
Md. I. HOSSAIN et al.: A METAMATERIAL-EMBEDDED WIDE-BAND ANTENNA FOR THE MICROWAVE C-BAND

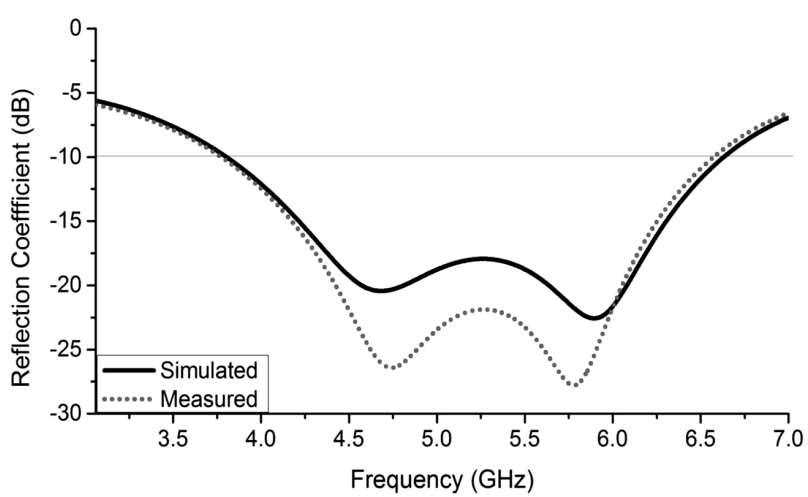

Figure 5: Simulated and measured reflection coefficient of the proposed antenna

Slika 5: Simuliran in izmerjen koeficient odseva predlagane antene

the printed-circuit technique for measurement in an anechoic chamber. The total antenna dimensions are 36 $\times 20 \times 0.8 \mathrm{~mm}$. At first, the proposed antenna is considered as a simple microstrip patch antenna with full ground plane (g-1), as indicated in Figure 2a. Secondly, a partial ground plane ( $\mathrm{g}-2)$ is used to get a wide bandwidth. Finally, a slotted partial ground plane $(g-3)$ is taken for the least back reflections. The reflection coefficient of the antenna with three different ground plane configurations is plotted in Figure $\mathbf{2 b}$. The reflection coefficients of the proposed antenna with and without the metamaterial are plotted in Figure 3. The results indicate that the incorporation of the proposed metamaterial with an antenna leads to a dramatically wider antenna impedance bandwidth. The surface current distributions of the proposed metamaterial antenna are given in Figure 4 comprising frequencies at $4.5 \mathrm{GHz}, 5 \mathrm{GHz}$, and $5.5 \mathrm{GHz}$ considering a zero phase of the input signal. The results show that the lower frequency response of the antenna depends significantly on the antenna patch. On the other hand, the antenna patch length does not affect the response of the antenna at the upper frequencies.

\section{ANALYSIS AND RESULTS}

According to Figure 5, the proposed antenna exhibits a wide bandwidth $2.81 \mathrm{GHz}$ (from $3.77 \mathrm{GHz}$ to 6.58

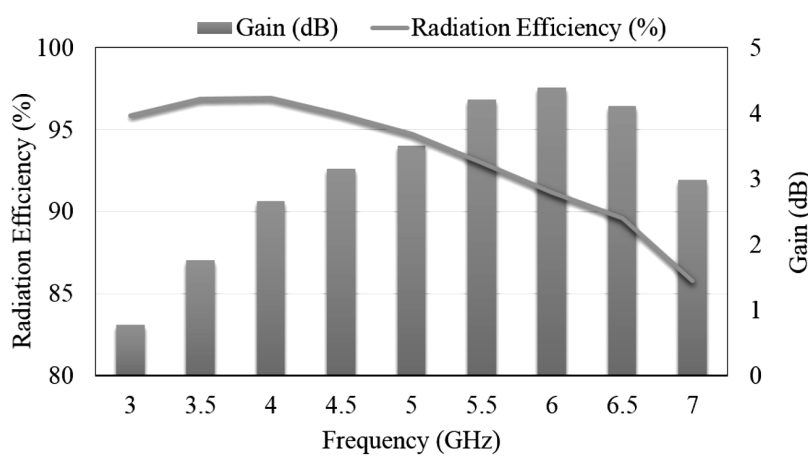

Figure 6: Peak gain and radiation efficiencies of the proposed antenna Slika 6: Največji izkoristek in učinkovitost sevanja predlagane antene
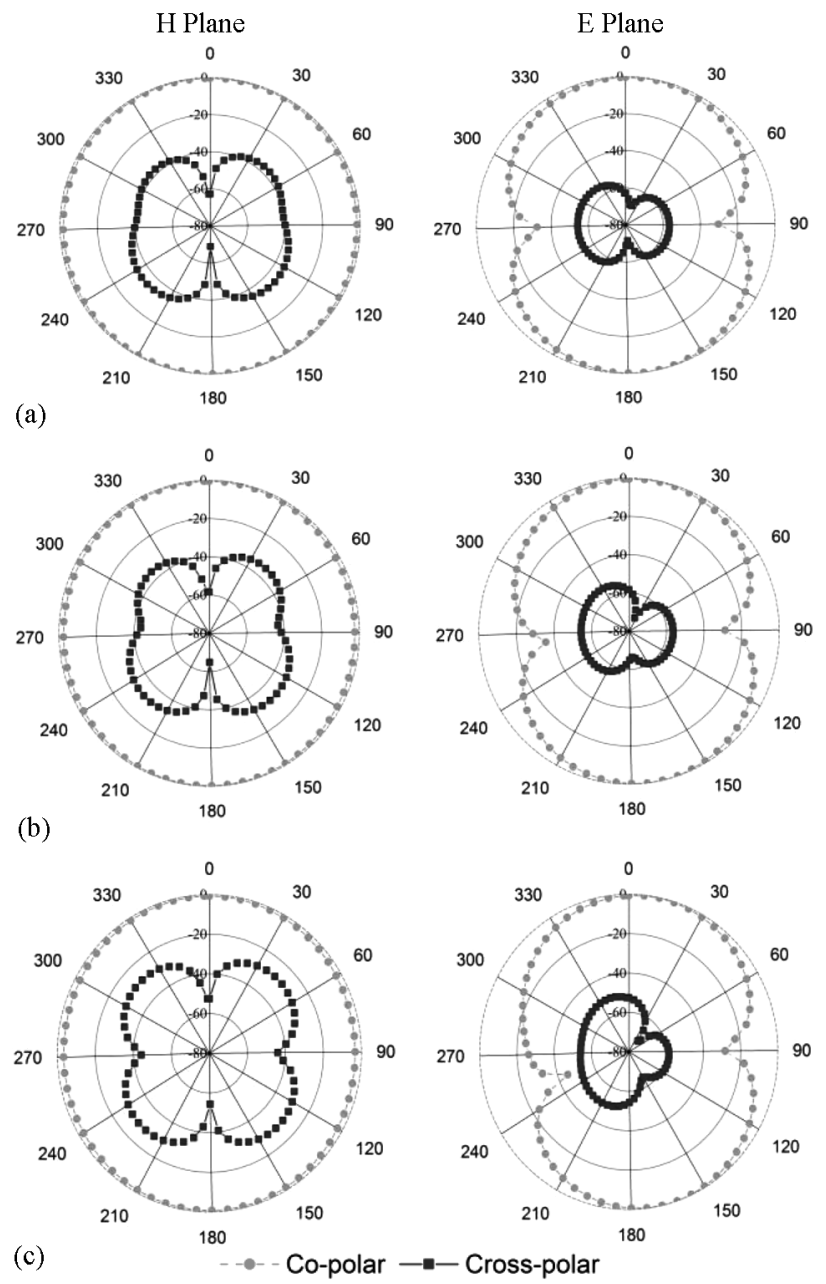

Figure 7: Radiation pattern at: a) $4.5 \mathrm{GHz}$, b) $5 \mathrm{GHz}$, and c) $5.5 \mathrm{GHz}$ Slika 7: Diagram sevanja pri: a) $4,5 \mathrm{GHz}$, b) $5 \mathrm{GHz}$ in c) $5,5 \mathrm{GHz}$

$\mathrm{GHz}$ ). Very good agreement is observed between the measured and simulated results, indicating an almost identical bandwidth. According to the measured reflection coefficient, the antenna's fractional bandwidth is $54.97 \%$ at the central frequency. The measured results of the peak gain and radiation efficiency of the proposed antenna are plotted in Figure 6. The antenna radiation efficiency varies from $85 \%$ to $97 \%$ for different frequencies.

On the other hand, the proposed antenna exhibits an antenna peak gain from $1 \mathrm{~dB}$ to $4.5 \mathrm{~dB}$ for different frequencies. However, the proposed antenna shows very good radiation efficiency and gain over the operating frequency range of the antenna. Figure 7 indicates the measured gain radiation pattern of the proposed antenna at $4.5 \mathrm{GHz}, 5 \mathrm{GHz}$, and $5.5 \mathrm{GHz}$. The results show near omni-directional radiation patterns in the $\mathrm{H}$ plane. The results at other frequencies of the $\mathrm{C}$ band exhibit very similar patterns as plotted, indicating stable radiation patterns are obtained. The radiation patterns of the proposed antenna are quite similar to the planar quarterwavelength mono-pole antenna. ${ }^{13}$ 


\section{MATERIALI IN TEHNOLOGIJE/MATERIALS AND TECHNOLOGY (1967-2017) - 50 LET/50 YEARS}

\section{Md. I. HOSSAIN et al.: A METAMATERIAL-EMBEDDED WIDE-BAND ANTENNA FOR THE MICROWAVE C-BAND}

\section{CONCLUSIONS}

In this paper, a wide-band antenna for microwave C-band application is proposed. The bandwidth enhancement is obtained using metamaterial incorporation with an antenna patch. The results indicate that the proposed antenna exhibits a wide impedance bandwidth from 3.77 $\mathrm{GHz}$ to $6.58 \mathrm{GHz}$. The results also indicate good radiation efficiency and antenna gain with a nearly omnidirectional radiation pattern at the frequencies of interest. This antenna can be used in long-distance radar communication systems.

\section{REFERENCES}

${ }^{1}$ H. Elsadek, Microstrip Antennas for Mobile Wireless Communication Systems, INTECH Open Access Publisher, 2010, doi:10.5772/ 7705

${ }^{2}$ D. M. Pozar, Microstrip antennas, The Proceedings of IEEE, 80 (1992) 1, 79-91, doi:10.1109/5.119568

${ }^{3}$ T. Alam, M. R. I. Faruque, M. T. Islam, N. Misran, Compositematerial printed antenna for a multi-standard wireless application, Mater. Tehnol., 49 (2015) 5, 745-749, doi:10.17222/mit.2014.232

${ }^{4}$ R. Garg, Microstrip antenna design handbook, Artech House, 2001

${ }^{5}$ J. Lao, R. Jin, J. Geng, Q. Wu, An ultra-wideband microstrip elliptical slot antenna excited by a circular patch, Microwave and Optical Technology Letters, 50 (2008) 4, 845-846, doi:10.1002/ mop. 23240
${ }^{6}$ L. Yousefi, B. Mohajer-Iravani, O. M. Ramahi, Enhanced bandwidth artificial magnetic ground plane for low-profile antennas, IEEE Antennas and Wireless Propagation Letters, 6 (2007), 289-292, doi:10.1109/LAWP.2007.895282

${ }^{7}$ B. L. Ooi, S. Qin, M. S. Leong, Novel design of broad-band stacked patch antenna, IEEE Transactions on Antennas and Propagation, 50 (2002) 10, 1391-1395, doi:10.1109/TAP.2002.802087

${ }^{8}$ J. Y. Sze, K. L. Wong, Bandwidth enhancement of a microstripline-fed printed wide-slot antenna, IEEE Transactions on Antennas and Propagation, 49 (2001) 7, 1020-1024, doi:10.1109/8.933480

${ }^{9}$ J. Y. Jan, J. W. Su, Bandwidth enhancement of a printed wide-slot antenna with a rotated slot, IEEE Transactions on Antennas and Propagation, 53 (2005) 6, 2111-2114, doi:10.1109/TAP.2005.848518

${ }^{10}$ N. Engheta, Nader, Richard W. Ziolkowski, eds. Metamaterials: physics and engineering explorations, John Wiley \& Sons, (2006), ISBN: 978-0-471-76102-0

${ }^{11}$ R. C. Hadarig, M. E. De Cos, F. Las-Heras, Microstrip patch antenna bandwidth enhancement using AMC/EBG structures, International Journal of Antennas and Propagation, 2012 (2011), doi:10.1155/ 2012/843754

${ }^{12}$ H. Xiong, H. O. N. G. Jing-Song, T. A. N. Ming-Tao, L. I. Bing, Compact microstrip antenna with metamaterial for wideband applications, Turkish Journal of Electrical Engineering and Computer Science, 21 (2013) 2, 2233-2238, doi:10.3906/elk-1204-6

${ }^{13}$ M. R. I. Faruque, M. I. Hossain, M. T. Islam, Low specific absorption rate microstrip patch antenna for cellular phone applications, IET Microwaves, Antennas \& Propagation, 9 (2015) 14, 1540-1546, doi:10.1049/iet-map.2014.0861 